\title{
Kedudukan dan Peranan Perempuan dalam Bidang Ekonomi Masa Bali Kuno Abad IX-XII Masehi
}

\author{
Ni Putu Sonia Asih \\ Prodi Arkeologi, Fakultas Ilmu Budaya, Unud \\ [soniaasih25@gmail.com]
}

\begin{abstract}
Abstrak
Studi ini difokuskan terhadap prasasti masa Bali Kuno abad IX-XII Masehi yang menyebutkan adanya tokoh-tokoh perempuan. Kemunculan tokoh-tokoh perempuan tersebut mempunyai kemampuan dan peranan yang penting dalam pemerintahan. Tujuan penelitian ini ialah untuk mengetahui bagaimana kedudukan dan peranan perempuan dalam bidang ekonomi pada masa Bali Kuno abad IX-XII Masehi. Penelitian ini menggunakan beberapa metode pengumpulan data, analisis data dan teori untuk memecahkan permasalahan. Metode pengumpulan data yang digunakan adalah observasi, studi pustaka, dan wawancara. Pada tahapan selanjutnya diolah dengan menggunakan analisis kualitatif, analisis kontekstual, analisis komparatif, dan analisis etnoarkeologi.Teori yang digunakan dijadikan dasar acuan dalam penelitian ini adalah teori postfeminisme, teori struktural fungsional dan teori perkembangan perdagangan. Hasil penelitian ini mengungkapkan bahwa kedudukan dan peranan perempuan dalam bidang ekonomi pada masa Bali Kuno abad IX-XII Masehi yaitu sebagai perajin, sebagai petani, sebagai seniman/seniwati, dan sebagai pedagang. Peranan perempuan pada masa itu terlihat dalam berbagai proses yaitu proses produksi, distribusi, dan konsumsi.
\end{abstract}

Kata kunci: Kedudukan, peranan, perempuan.

\begin{abstract}
This study focused on the data of ancient Balinese inscriptions IX-XII century AD, some of the female figures were mentioned. The emergence of these female figures has important capabilities and roles in government. The purpose of this study is to find out how the status and roles of women in the economic field in the period of the ancient Balinese IX-XII century AD. This study used several methods of data collection, data analysis and theories to answer the problems. Methods of data collection used were observation, literature study, and interview. In the next stage, it was processed by using qualitative analysis, contextual analysis, comparative analysis, and ethnoarkeology analysis. The theories used as the basis of reference in this research were the theory of postfeminism, functional structural theory and commercial development theory. The results of this study reveal that the status and roles of women in the economic field during the ancient Balinese century IX-XII AD is as crafters, farmers, artists, and as traders. The roles of women at that time is seen in various processes namely the process of production, distribution, and consumption.
\end{abstract}

Keywords: status, roles, woman.

\section{Latar Belakang}

Perbedaan antara laki-laki dan perempuan dapat disebabkan oleh faktor budaya yang tercipta dalam masyarakat sehingga perempuan didominasi oleh

laki-laki. Laki-laki dianggap memiliki fisik yang kuat, pintar dan dapat diandalkan dibandingkan perempuan yang dianggap memiliki fisik yang lemah, lembut, dan halus. Perbedaan 
antara laki-laki dan perempuan tersebut menyebabkan berkembangnya istilah gender. Istilah gender digunakan oleh para ilmuwan sosial untuk menjelaskan perbedaan perempuan dan laki-laki dalam masyarakatnya. Pengaruh gender telah melahirkan perbedaan peran, tanggung jawab, fungsi, bahkan ruang tempat dimana manusia beraktivitas (Puspitawati, 2012: 1).

Perhatian terhadap masalah perempuan dalam disiplin arkeologi telah dimulai sejak abad XIX pada saat feminisme merasuk ke dalam dunia ilmu pengetahuan, sehingga gender mulai menjadi topik bahasan dalam arkeologi. Arkeologi gender mencakup tema-tema yang berbeda, yaitu koreksi terhadap bias laki-laki dalam arkeologi, kritikan terhadap struktur yang ada dalam praktek-praktek arkeologi, penafsiran kembali dari sejarah arkeologi, menguji gender dengan data arkeologi, dan terhadap apa yang dilihat sebagai bias laki-laki dianggap lazim dalam pengetahuan akademik dan dunia akademik secara umum (Johnson dalam Nastiti, 2016: 6).

Berdasarkan data prasasti masa Bali Kuno abad IX-XII Masehi dapat diungkap berbagai aspek sosial budaya pada masa lampau, seperti penjelasan mengenai kronologi suatu hal yang terjadi pada masa lampau, organisasi sosial kemasyarakatan yang meliputi struktur kerajaan, struktur masyarakat termasuk berbagai jabatan, hak dan kewajiban pejabat dan rakyat, sistem mata pencaharian hidup, sistem religi, dan sistem kepercayaan. Khususnya penjelasan mengenai kegiatan ekonomi sangat banyak ditemukan dalam prasastiprasasti yang telah ditemukan pada masa Bali Kuno abad IX-XII Masehi.

Masyarakat Bali Kuno abad IXXII Masehi telah mengenal adanya sistem pembagian pekerjaan antara lakilaki dan perempuan. Sistem pembagian pekerjaan tersebut menyangkut mata pencaharian penduduk pada masa itu. Kehidupan masyarakat Bali Kuno mengenal beberapa pekerjaan yang tidak hanya dilakukan oleh laki-laki tetapi juga dilakukan oleh perempuan seperti kegiatan kerajinan, perdagangan, pekerja seni, petani, dan kegiatan lainnya. Salah kegiatan yang mencerminkan adanya pembagian pekerjaan yaitu dalam bidang perdagangan, yang dibuktikan dengan adanya istilah wanigrama (saudagar lakilaki) dan wanigrami (saudagar perempuan) yang membuktikan adanya peranan perempuan dalam kegiatan perdagangan (Poesponegoro, 2008:373).

Berdasarkan penjelasan tersebut dirasa perlu untuk dilakukan penelitian lebih mendalam mengenai "Kedudukan Dan Peranan Perempuan Dalam Bidang Ekonomi Masa Bali Kuno Abad IX-XII Masehi”.

\section{Pokok Permasalahan}

Berdasarkan apa yang telah dijelaskan dalam latar belakang permasalahan, muncul beberapa pertanyaan adalah sebagai berikut.

1. Bagaimana kedudukan perempuan dalam bidang ekonomi pada masa Bali Kuno abad IX-XII Masehi ?

2. Bagaimana peranan perempuan dalam bidang ekonomi pada masa Bali Kuno abad IX-XII Masehi ?

\section{Tujuan Penelitian}

Adapun tujuan dari penelitian ini, sebagai berikut. 1) Untuk mengetahui kedudukan perempuan dalam bidang ekonomi pada masa Bali Kuno abad IXXII Masehi. 2) Untuk mengetahui peranan perempuan dalam bidang ekonomi pada masa Bali Kuno abad IXXII Masehi 


\section{Metode Penelitian}

Penelitian ini adalah pendekatan dengan metode kualitatif. Penelitian kualitatif merupakan teknik pengumpulan data yang berupa tulisan, rekaman, gambaran, relief-relief, dan berbagai data yang lain yang ditransformasikan atau dibuat dalam bentuk teks. Penelitian ini menggunakan prasasti masa Bali Kuno abad IX-XII Masehi sebagai data primer dan menggunakan laporan penelitian, relief-relief, data etnografi sebagai data sekunder.

Teknik pengumpulan data yang digunakan dalam penelitian ini yaitu: Studi pustaka, observasi, dan wawancara yang mendalam dari masyarakat di lokasi penelitian yaitu di Desa Buahan Kintamani, Desa Serai Kintamani, Desa Kintamani, Desa Kayubihi Bangli, Desa Tenganan Pegringsingan, dan Desa Kamasan Klungkung sebagai data sekunder dalam penelitian ini.

Analisis yang dilakukan dalam penelitian ini yaitu analisis kualitatif untuk mengguraikan data dalam bentuk deskriptif, selanjutnya analisis kontekstual untuk hubungan antara data yang ada dalam satu prasasti maupun hubungan antara prasasti yang dikeluarkan oleh raja yang sama. Analisis lainya yaitu analisis komparatif yang dilakukan untuk membandingkan kedudukan dan peranan perempuan di jawa pada periode yang sama dengan kedudukan dan peranan perempuan di bali pada masa Bali Kuno abad IX-XII Masehi dan menggunakan perbandingan dengan data relief di Jawa pada periode yang sama. Penelitian ini juga menggunakan analisis etnoarkeologi untuk melakukan persamaan atau analogi mengenai kedudukan dan peranan perempuan dalam bidang ekonomi pada masa kini dengan kedudukan dan peranan perempuan dalam bidang ekonomi pada masa Bali Kuno Abad IX-XII Masehi.

\section{Hasil dan Pembahasan}

Masyarakat Bali Kuno telah mengenal adanya pembagian pekerjaan terutama dalam bidang ekonomi. Pembagian pekerjaan tersebut antara lakilaki dan perempuan, antar perempuan ataupun antar laki-laki sesuai dengan kemampuan yang dimiliki. Adanya pembagian pekerjaan tersebut menyebabkan terciptanya kedudukan dan peranan masing-masing individu laki-laki dan perempuan dalam masyarakatnya, khususnya terkait dengan aktivitas ekonomi pada masa itu. Kedudukan dan peranan tersebut dijelaskan sebagai berikut.

\subsection{Kedudukan dan peranan perempuan dalam bidang ekonomi masa Bali Kuno abad IX-XII Masehi}

Kedudukan perempuan dalam bidang ekonomi merupakan posisi seorang perempuan dalam kegiatan perekonomian di masyarakat. Berdasarkan sumber-sumber prasasti pada masa Bali Kuno abad IX-XII masehi, maka ditemukan kedudukan perempuan dalam bidang ekonomi pada masa itu. Kedudukan perempuan pada masa Bali Kuno akan dijelaskan sebagai berikut.

1. Kedudukan dan Peranan Perempuan dalam Bidang Kerajinan

Data prasasti yang menunjukan perempuan sebagai perajin yaitu Pengotan A1 846 Saka yang isinya yaitu:

IIa. 3. "..., tathapi anada rggapna wawinina, sulpika, tahu di tkapan, pande bsi,

4.mas, pamukul, majahit kajag, macadar, mangikat, mangnila, mamangkudu, marundan tani 
kabakatěn matikasan,...", (Goris, 1945:67-68).

Artinya:

IIa. 3. "..., tetapi jika ada kepala keluarganya, wanitanya sebagai artis tahu mengerjakan pande besi

4. pande mas, pemain musik, penjahit kajang, pembuat kain cadar, menenun, mencelup dengan warna biru, mencelup dengan warna merah, tukang jahit tidak dikenai pajak tikasan,..", (Ardika dan Beratha, 1996: 84-86 ).

Prasasti tersebut menjelaskan apabila ada perempuan yang bekerja sebagai sulpika (perajin/artis) tidak dikenakan pajak oleh raja. Berdasarkan penjelasan tersebut, memberikan informasi bahwa adanya kaum perempuan yang terlibat dalam bidang kerajinan dan memiliki kedudukan sebagai perajin.

Menurut data prasasti tersebut, maka perempuan memiliki peranan dalam bidang kerajinan terutama kerajinan tekstil atau kain. Seperti kerajinan tenun yang melibatkan perempuan dalam proses pembuatanya. Berdasarkan data etnografi di Tenganan Pegringsingan para perempuan melakukan kegiatan tenun dari usia 18-30 tahun. Selain itu, menurut Saraswati (2016:116) Perempuan membuat barangbarang kerajinan seperti kain, barangbarang anyaman, barang-barang dari tanah liat, gula, minyak, dan sebagainya yang dilakukan di sela-sela kesibukan bekerja di sawah/ladang dan menyelesaikan tugas-tugas rumah tangga, kemudian hasilnya digunakan untuk keperluan sendiri dan dijual.

Kegiatan kerajinaan lainnya yang dilakukan seperti kerajinan gerabah, kerajinan logam, kerajinan kayu, dan kerajinan anyaman yang memerlukan ikut serta perempuan dalam proses pembuatanya. Hal tersebut karena dalam pengerjaannya diperlukan ketelitian, kesabaran, dan keterampilan dalam pembuatanya untuk mendapatkan hasil kerajinan yang indah. Peranan perempuan dalam pembuatanya yaitu dalam kegiatan yang bersifat perempuan atau kegiatan yang memerlukan tenaga yang lebih sedikit seperti kegiatan pemintalan benang, pembuatan pola kain, pewarnaan dalam kerajinan tekstil/kain. Kegiatan pengecatan, pengamplasan, dan pengamplasan dalam kerajinan kayu dan logam. Kegiatan membuat pola hias dalam gerabah, pembuatan gerabah, penjemuran gerabah dalam kerajinan gerabah. Kegiatan menganyam, dan pewarnaan dan kegiatan-kegiatan lainnya dalam kerajinan anyaman.

\section{Kedudukan dan Peranan Perempuan dalam Bidang Pertanian}

Kegiatan pertanian dapat dilihat dari adanya data prasasti yang menyebutkan Hasil-hasil perkebunan tersebut seperti berbagai jenis umbi -umbian (mulaphala), berbagai jenis buah-buahan (sarwaphala), sayur-sayuran (gangan), dan berbagai biji-bijian (sarwawija) yang diperdagangkan ataupun digunakan untuk memenuhi kebutuhan sehari-hari.

Penjelasan tersebut menunjukan bahwa kegiatan pertanian yang telah dilakukan oleh masyarakat pada masa Bali Kuno abad IX-XII Masehi. Dalam kegiatan pertanian tersebut, maka terdapat pelaku-pelaku pertanian yang disebut dengan petani. Namun, data prasasti pada masa itu tidak menyebutkan jenis kelamin petani. Berdasarkan data etnografi di Desa Bwahan dan Desa Serai Kecamatan Kintamani menjelaskan adanya perempuan dan laki-laki melakukan kegiatan pertanian sebagai pekerjaan utamanya, seperti bertani jeruk, bawang dan sayur-sayuran lainnya.

Menurut sumber relief yang terdapat dalam umpak yang ditemukan di 
Trowulan dan relief yang terdapat dalam Candi Rimbi mengambarkan kegiatan perempuan yang sedang memanen. Data artefaktual lainnya yang menjelaskan adanya kegiatan pertanian yaitu Relief Karmawibhangga yang terdapat di Candi Borobudur yaitu panil O118 dan $\mathrm{O} 122$ mengambarkan adanya kegiatan pertanian yang dilakukan oleh laki-laki dan perempuan (Nastiti, 2016: 276-278).

Penjelasan tersebut dapat menjelaskan adanya perempuan pada masa Bali Kuno abad IX-XII Masehi yang melakukan kegiatan pertanian. Data prasasti lainnya menunjukan adanya tahapan atau proses kegaitan pertanian yaitu Tengkulak A 945 Saka yang isinya sebagai berikut.

IIb. 5. "..., tan kna ring bunçang haji, tkapning salen, kadyangganing, mangir bahan, lancang, sambo, mamantilan, tunda tunda, amaba 6. ki amuluku, atanem, amantun, ahani, anutu, tan kna sakwaih ning bu ñcang haji, tkengatagatagan salwiranya prakāra, mwang tan wadungan nyu, kayu pucang,.." (Ardika dan Beratha, 1998: 89-90).

Artinya:

IIb. 5. “..., selanjutnya tidak kena kerja rodi di tempat lain seperti menyiapkan bahan, sampan, sambo, wantilan, teras, membuka lahan,

6. membajak, menanam, menyiangi, menuai, menumbuk, tidak kena semua jenis kerja rodi, dan segala perintah lainya dan tidak menebang kelapa, kayu pinang,... "(Ardika dan Beratha, 1998: 89-90).

Berdasarkan kutipan prasasti tersebut maka peranan perempuan dalam kegiatan pertanian lahan basah pada masa Bali Kuno abad IX-XII Masehi yaitu ikut serta dalam kegiatan menanam padi (atanem), menyiangi (amantun), menuai padi (ahani), dan menumbuk padi (anutu). Selain itu dalam kegiatan mangharañi juga dilakukan oleh perempuan, sedangkan kegiatan seperti, menyiapkan lahan dan membajak sawah dilakukan oleh kaum laki-laki. Proses selanjutnya yaitu menumbuk padi menjadi beras. Proses menumbuk padi biasannya dilakukan oleh perempuan. Menumbuk padi biasanya dilakukan oleh perempuan menggunakan lumpang dan alu (Nastiti, 2016: 266)

Kegiatan pertanian lahan kering atau perladangan juga berkembang pada Masa Bali Kuno abad IX-XII Masehi. Dalam kegiatan perladangan atau perkebunan juga terdapat pembagian pekerjaan antara laki-laki dan perempuan. Beberapa tahapan perkebunan sesuai dengan tumbuhan yang akan di tanam yaitu seperti membuka lahan sampai dengan pemanenan secara umum proses pekerjaan di perkebunan yaitu: menyiapkan lahan sehingga siap untuk ditanami yang biasanya dilakukan oleh laki-laki, membuat petak-petak tanah untuk menempatakan bibit tanaman yang biasanya dilakukan oleh laki-laki, penanaman atau penempatan bibit tanaman dapat dilakukan oleh kaum lakilaki dan perempuan, namun sebagian besar dilakukan oleh kaum perempuan, dan pemberian pupuk dapat dikerjakan oleh laki-laki dan perempuan serta yang terakhir tahap pemanenan yang dapat dilakukan oleh laki-laki dan perempuan (Tim Psg Stain Pekalongan, 2010:216217).

Uruian di atas dapat menggambarkan adanya kegiatan pertanian yang dilakukan oleh perempuan pada masa Bali Kuno Abad IX-XII Masehi.

3. Kedudukan dan Peranan Perempuan dalam Bidang Kesenian

Data prasasti pada masa Bali Kuno abad IX-XII Masehi menjelaskan adanya 
seni yang berkembang pada masa itu adalah seni pertunjukan (bandhagina), seni lukis (citrahara), dan seni pahat (amahat) (Munandar, dkk, 2012: 83).

Prasasti Sembiran AI 844 Saka menyebutkan adanya kegiatan kesenian yang dilakukan pada masa Bali Kuno abad IX-XII Masehi yang isinya yaitu:

IIb. 4. "..., parmasan pamukul ma 1 pi 2 turut sarungañ̃a, me sarb, sangkha, tani kadan,

5. parcaksuna, pabharu, tani kranganyan,..." (Goris, 1954:66).

Artinya:

IIb. 4. "..., iuran untuk tarian kerasukan dan penabuh gamelan sebanyak 1 masaka dan 2 piling. Turut juga sarungan dan sarb (alat musik), sangka (kalasangka),

5. tidak dikenakan pajak caksu (mata-mata), pajak penduduk baru, dan juga tidak dikenakan pajak bagi mereka yang meninggal tanpa mempunyai keturunan,..", (Ardika dan Beratha, 1996: 43).

Prasasti ini menjelaskan bahwa para pelaku seni, khusunya seni pertunjukan yang melakukan kegiatan untuk upacara keagamaan tidak dikenai pajak. Kesenian-kesenian yang terdapat pada masa itu juga merupakan salah satu mata pencaharian masyarakat pada masa itu. Hal tersebut, dikarenakan berdasarkan data-data tekstual, masyarakat yang bekerja dalam bidang seni wajib membayar pajak dan mendapatkan upah yang diberikan sesuai dengan aturan yang telah ditetapkan oleh pemerintah pada masa itu. Terutama dalam seni pertunjukan, para pemain seni pertunjukan mendapatkan upah sesuai dengan jenis kesenian yang di tampilkan karena telah menghibur para raja dan masyarakat.

Data tekstual yang menunjukan adanya kegiatan kesenian cukup banyak, namun tidak dijelaskan jenis kelamin para pelaku seni. Jenis kelamin pelaku seni dapat ditunjukan melalui data etnografi dan data relief dalam candicandi di Jawa. Seperti adanya istilah seniwati pada masa kini yang dapat menunjukan jenis kelamin para pelaku seni. Menurut Kamus Besar Bahasa Indonesia (KBBI) seniwati merupakan perempuan yang ahli menciptakan karya seni atau seniman perempuan (Tim Penyusun, 1990: 817).

Prasasti masa Jawa Kuno yaitu salah satunya prasasti Poh menyebutkan adanya kedudukan dan peranan perempuan dalam kegiatan kesenian yang isinya IIb. 5. "..., rara mabhumana tinonton si karigna, darini, muan, si rumpuk, muan werewerehnya si jaway, si baryyut" , yang artinya gadis-gadis keliling untuk ditonton ialah si Ksrigna, si Darini, dan si Rumpuk, dengan pengiringnya si Jaway, si Baryyut. Berdasarkan prasasti tersebut perempuan memiliki peranan dalam kegiatan menari yang dipentaskan dalam upacara penetapan sima pada masa itu. Reliefrelief dan prasasti pada masa Jawa Kuno juga menjelasakan bahwa adanya perempuan dalam dunia seni pertunjukan seperti menari dan memainkan musik yang kemungkinan dilakukan oleh perempuan Bali pada masa itu (Nastiti, 2016:283).

Menurut Swarsi, dkk (1989: 73) bahwa kedudukan Perempuan Bali dalam bidang kesenian. Menurutnya perempuan Bali memiliki kedudukan yang cukup menonjol dalam bidang kesenian, seperti sebagai penari (tari arja, tari legong, tari jangger, tari joged, tari rejang, drama gong, sendra tari dan berbagai jenis tarian di daerah Bali). Kegiatan lainnya yang dilakukan perempuan seperti kegiatan menyanyi yang untuk upacara agama (mekidung), menyanyi lagu-lagu yang populer dan juga sebagai dalang perempuan. Perempuan-perempuan tersebut dilatih dari kecil sehingga dapat melakukan kegiatan seperti menari dan 
menyanyi dengan baik, khususnya yang terkait dengan upacara agama. Seperti yang terdapat dalam masyarakat Tenganan Pegringsingan perempuanperempuan remaja wajib mengikuti kegiatan pendidikan yang terkait dengan kesenian, salah satunya adalah seni suara, seni suara yang diajarkan adalah mekidung (nyanyian untuk upacara keagamaan).

Data artefaktual juga menunjukan adanya perempuan yang terlibat dalam dunia kesenian seperti Relief cerita Awanda dan Jataka dalam Candi Borobudur panil IBb 44 yang melukiskan keluarga bangsawan menonton dua orang perempuan yang sedang menari (Nastiti, 2016: 284)

Kesenian lainnya yang melibatkan perempuan yaitu seperti seni lukis. Seperti data etnogragi yang menjelaskan adanya seni lukis yang berkembang salah satunya Seni Lukis Wayang Kamasan. Teknik pembuatan lukisan Wayang Kamasan sampai saat ini masih menggunakan cara-cara tradisional antara lain pembuatan kanvas (nganjinin/mubuhin), membuat seketn (ngreka), mewarna dan memberi ornamen (nyawi). Proses pembuatan lukisan wayang kamasan ini menunjukan adanya pembagian pekerjaan antara lakilaki dan perempuan. Pembagian pekerjaan tersebut berupa peranan perempuan dalam hal pembuatan skets (ngreka) dan pewarnaan serta pemberian ornamen. Dalam pekerjaan tersebut, tidak hanya dilakukan laki-laki, tetapi juga dilakukan oleh perempuan sesuai dengan keterampilan yang dimiliki.

Penjelasan di atas memberikan gambaran terkait adanya kedudukan dan peranan perempuan dalam kegiatan kesenian pada masa Bali Kuno abad IXXII Masehi.

4. Kedudukan dan peranan perempuan dalam kegiatan perdagangan
Data prasasti masa Bali Kuno abad IX-XII Masehi menunjukan adanya wanigrami (saudagar perempuan) dan Juru wanigrami (pemimpin saudagar perempuan). Istilah tersebut menjelasakan bahwa adanya kaum perempuan yang mendapatkan posisi atau kedudukan sebagai pedagang atau saudagar perempuan. Hal tersebut membuktikan perdagangan tidak hanya dilakukan oleh kaum laki-laki, namun dalam aktivitasnya juga dilakukan oleh kaum perempuan. Mengenai adanya kedudukan perempuan dalam bidang perdagangan pada masa Bali Kuno abad IX-XII Masehi dapat dilihat dari prasasti Dawan 975 Saka yang isinya sebagai berikut.

IIIa. 5. $i$ harpen tanda rakryan makabehan makadi para senāpati, makasaksi karaman para sandhibisa irikanang wanigrama wanigrami kajawan (Ardika dan Beratha, 1998: 132173).

Artinya:

IIIa. 5. itu berhadapan dengan para tanda rarkyan semuanya seperti para senāpati, penduduk desa sebagai saksi para sandhibisa disana juga terdapat saudagar laki-laki dan saudagar perempuan kajawan, (Ardika dan Beratha, 1998: 132173).

Istilah wanigrama wanigrami juga muncul dalam prasasti Jawa Kuno yang disebut dengan banigrama banigrami. Banigrama banigrami merupakan kelompok untuk para saudagar yang lebih besar yang melakukan perdagangan antar pulau. Hal ini sesuai dengan pendapat Abdullah (2001:125) yang menyatakan kaum perempuan lebih tepat mempunyai mata pencaharian sebagai pedagang karena dianggap lebih mampu dan lebih 
telaten dibandingkan laki-laki ketika tawar menawar.

Peranan perempuan dalam bidang perdagangan terlihat dari adanya barang dagangan yang dijual. Seperti barang kebutuhan sehari-hari dan kerajinan biasanya lebih banyak dilakukan oleh perempuan. Menurut pendapat Stepanie (2008:1-5) perdagangan jenis kebutuhan sehari-hari dan hasil kerajinan dapat dilakukan oleh kaum perempuan ataupun laki-laki dengan barang dagangan khas perempuan ataupun laki-laki atau sebagian besar dilakukan oleh kaum perempuan seperti perabotan rumah tangga. Berdasarkan data etnografi di Desa Tenganan dan Desa Kintamani, maka kegiatan penjualan seperti hasil tenun, perdagangan pakaian, anyaman buah-buahan, dan sayur-sayuran, baik dengan menetap disebuah pasar ataupun dengan berjualan keliling. Barang-barang lainnya seperti binatang ternak lebih banyak dilakukan oleh laki-laki namun untuk binatang kecil seperti unggas dan ayam dapat dilakukan oleh perempuan.

\section{Simpulan}

Berdasarkan uraian yang telah dijelaskan pada bab sebelumnya, maka pada bagian ini disampaikan beberapa simpulan. Kedudukan dan peranan perempuan dalam bidang ekonomi pada masa Bali Kuno abad IX-XII Masehi yaitu:

1. Kedudukan dan peranan perempuan dalam bidang kerajinan yaitu peranan perempuan dalam bidang kerajinan yaitu seperti dalam kerajinan tekstil yang lebih banyak dilakukan oleh kaum perempuan, kerajinan kayu, kerajinan logam dan kerajinan batu. Perempuan memiliki peranan dari kegiatan produksi, sampai dengan pengepakan atau finishing dan pengangkutan.
2. Kedudukan dan peranan perempuan dalam bidang pertanian yaitu peranan perempuan dari membuka lahan sampai dengan pemanenan. Peranan perempuan dalam bidang pertanian yaitu menanam benih, penuai dan pembuat serta pelaksana upacara yang berhubungan dalam bidang pertanian.

3. Kedudukan dan peranan perempuan dalam bidang kesenian, istilah seniwati dapat membuktikan adanya peranan perempuan dalam dunia seni. Sehingga, perempuan tidak hanya sebagai objek seni tetapi juga menjadi sumber penghasilan keluarga dan ada perempuan professional dalam bidang seni pertunjukan. Dalam bidang seni lukis, perempuan melakukan kegiatan mewarnai dan membuat sketsa.

4. Kedudukan dan peranan perempuan dalam bidang perdagangan, pedagang perempuan disebut dengan wanigrami. Kegiatan perdagangan dapat dilakukan di pasar atau berdagang keliling yang menjual barang kebutuhan sehari-hari, hasil kerajinan dan binatang ternak.

\section{Daftar Pustaka}

Abdullah, Irwan 2001. "Penelitian Berwawasan Gender dalam Ilmu Sosial". Jurnal Humaniora XV(3), hlm. 265-275.

Ardika, I Wayan dan N L Sutjiati Beratha. 1996. Perajin Pada Masa Bali Kuno Abad IX-XI M. Laporan Penelitian. Denpasar: Fakultas Sastra Udayana

Ardika, I Wayan dan N L Sutjiati Beratha. 1998. Perajin Pada Masa Bali Kuno Abad IX-XI M. Laporan Penelitian. Denpasar: Fakultas Sastra Udayana.

Goris, Roelof. 1954a. Prasasti Bali I. Bandung: Masa Baru

Munandar, Agus Aris, dkk. 2012. Seribu Tahun Wafatnya Prabu Udayana: Menggali Nilai 
Kearifan Untuk Membangun

Karakter Bangsa. Denpasar:

Udayana University Press.

Nastiti, Titi Sruti. 2016. Perempuan

Jawa Kedudukan dan

Peranannya dalam Masyarakat

Abad VIII-XV. Bandung: Pustaka

Jaya.

Poesponegoro, Marwati Djoened. 2008.

Sejarah Nasional Indonesia II.

Jakarta: Balai pustaka.

Puspitawati, Herien. 2012. Gender dan keluarga, Konsep Realita di Indonesia.

Saraswati, Ufi. 2016. Kuasa Perempuan dalam Sejarah Kuna Indonesia ,dalam Sejarah dan Budaya Tahun Kesepuluh, Nomor 1, Juni 2016, hlm.112-119. Malang: Universitas Negeri Malang

Stepanie, Arie. 2008. Strategi Nafkah Pedagang Perempuan di Sektor Informal Perkotaan (Studi Kasus Pedagang Perempuan di Pasar Anyar, Kota Bogor, Provinsi Jawa Barat).Skripsi. Bogor: Institut Pertanian Bogor.

Swarsi, Si Luh, dkk. 1986. Kedudukan dan Peranan Wanita Pedesaan Daerah Bali. Jakarta: Departemen Pendidikan dan Kebudayaan Proyek Inventarisasi dan Dokumentasi Kebudayaan Daerah Jakarta.

Tim Penyusun. 1990. Kamus Besar Bahasa Indonesia. Cet ke-3. Jakarta: Balai Pustaka.

Tim Psg Stain Pekalongan. 2010. "Peran Perempuan di Sektor Pertanian (Studi Kasus Pertanian Tebu di Kec. Pekalongan)", Muwazah vol. 2, hlm 216-226. 